\title{
Sien New Disease Reports \\ First report of Pectobacterium betavasculorum associated with bacterial vascular necrosis and root rot disease of sugar beet in Turkey
}

\author{
M. Ozturk ${ }^{1 *}$, Z. Eroglu ${ }^{1}$ and S. Soylu ${ }^{2}$ \\ ${ }^{1}$ Department of Plant Protection, Faculty of Agriculture, Yozgat Bozok University, Yozgat, Turkey; ${ }^{2}$ Department of Plant \\ Protection, Faculty of Agriculture, Hatay Mustafa Kemal University, Hatay, Turkey
}

*E-mail: muratzm66@gmail.com

Received: 25 Apr 2019. Published: 08 Jun 2019. Keywords: bacterial disease, Beta vulgaris, housekeeping genes, sequence analysis

\begin{abstract}
During June and September of 2018, bacterial necrosis and root rot disease surveys were conducted in sugar beet (Beta vulgaris) fields in Yozgat province in the Central Anatolia region of Turkey. From 33 fields surveyed, 19 sugar beet plants exhibiting vascular necrosis with blackened petioles, root rotting varying from wet to dry and wilting symptoms were collected for bacterial isolation. Sap from the margins of affected root tissue and petioles was streaked on crystal violet pectate (CVP) media and incubated at $28^{\circ} \mathrm{C}$ for 48 hours. Ten individual cavity-forming bacterial colonies were obtained on CVP media from petiole and roots of infected plants and transferred to nutrient agar for bacterial identification and pathogenicity tests. All bacterial isolates were gram negative, catalase positive, oxidase negative, facultative anaerobe, non-fluorescent on King's B medium, utilising gelatine, capable of eliciting hypersensitive response on tobacco plants (Nicotiana bentamiana) and caused soft rot symptoms on potato tuber slices. They were able to grow at $37^{\circ} \mathrm{C}$ and in Luria broth containing $5 \% \mathrm{NaCl}$, but not at $39^{\circ} \mathrm{C}$.
\end{abstract}

Bacterial DNA was extracted from a representative isolate (P12) pathogenic to sugar beet. The isolate did not produce a specific PCR amplicon with taxon-specific primers such as $\mathrm{Y} 1 / \mathrm{Y} 2$ for Pectobacterium spp., EXPCCF/EXPCCR for $P$. carotovorum subsp. carotovorum and Br1f/L1r for $P$. carotovorum subsp. brasiliense (Dees et al., 2017; Ozturk et $a l ., 2018)$. Isolate $\mathrm{P} 12$ was further characterised by sequence analysis using gapA and $m d h$ housekeeping genes with gapA-7-F/gapA-938-R and $m d h 86 \mathrm{~F} / m d h 628 \mathrm{R}$ primers, respectively (Ma et al., 2007; Cigna et al., 2017). Partial 701 and 452 bp nucleotide sequences (GenBank Accession Nos. MK689857 and MK689856) were subjected to BLAST analysis and had $96.0 \%$ sequence identity with the gapA gene of $P$. atrosepticum (SCRI1043; CP009125) and 100\% identity with $m d h$ gene of $P$. betavasculorum (CFBP2122 $2^{\mathrm{T}}$;N600343) isolated from sugar beet (Gardan et al., 2003). A phylogenetic tree based on the $m d h$ gene was constructed using maximum likelihood method, and clustered isolate P12 with $P$. betavasculorum CFBP $2122^{\mathrm{T}}$ and Ecb1 strains (Fig. 1).

A pathogenicity experiment was performed on 40-day-old sugar beet plants (cv. Turbata) at the eight-leaf stage by puncturing a hole (diameter $3-5 \mathrm{~mm}$ ) in three petioles per plant using a sterile pipette tip containing fresh single colonies grown on nutrient agar for 24 hours. After four days, vascular blackening of petioles including frothing occurred at the inoculation point. The leaves of infected petioles was half chlorotic seven days after inoculation (Fig. 2). Control petioles treated with sterile water remained symptomless. Re-isolated pectolytic bacterial colonies on CVP formed cavities and the isolates had the same biochemical and physiological features as the original culture.

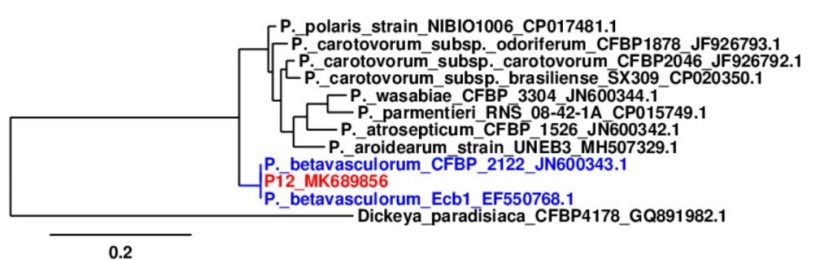

Figure 1
To the best our knowledge, this is the first report of $P$. betavasculorum causing bacterial vascular necrosis and root rot disease on sugar beet in Turkey. Disease on sugar beet caused by $P$. betavasculorum is widespread in Iran (Nedaienia \& Fassihiani, 2011) and control measures to prevent further spread of pathogen should be taken in the region.

\section{Acknowledgements}

This study was supported by financial grant of Yozgat Bozok University, project no. 6602c-ZF/18-190.

\section{References}

Cigna J, Dewaegeneire P, Beury A, Gobert V, Faure D, 2017. A gapA PCRsequencing assay for identifying the Dickeya and Pectobacterium potato pathogens. Plant Disease 101, 1278-1282. http://dx.doi.org/10.1094/PDIS-12-16-1810-RE

Dees MW, Lebecka R, Perminow JIS, Czajkowski R, Grupa A, Motyka A, Zoledowska S, Śliwka J, Lojkowska E, Brurberg MB, 2017.

Characterization of Dickeya and Pectobacterium strains obtained from diseased potato plants in different climatic conditions of Norway and Poland. European Journal of Plant Pathology 148, 839-851. http://dx.doi.org/10.1007/s10658-016-1140-2

Gardan L, Gouy C, Christen R, Samson R, 2003. Elevation of three subspecies of Pectobacterium carotovorum to species level: Pectobacterium atrosepticum sp. nov., Pectobacterium betavasculorum sp. nov. and Pectobacterium wasabiae sp. nov. International Journal of Systematic and Evolutionary Microbiology 53, 381-391. http://dx.doi.org/10.1099/ijs.0.02423-0

Ma B, Hibbing ME, Kim HS, Reedy RM, Yedidia I, Breuer J, Breuer J, Glasner JD, Perna NT, Kelman A, Charkowski AO, 2007. Host range and molecular phylogenies of the soft rot enterobacterial genera Pectobacterium and Dickeya. Phytopathology 97, 1150-1163. http://dx.doi.org/10.1094/PHYTO-97-9-1150

Nedaienia R, Fassihiani A, 2011. Host range and distribution of Pectobacterium betavasculorum, the causal agent of bacterial vascular necrosis and root rot of sugarbeet in Fars province. Iranian Journal of Plant Pathology 47, 179-185.

Ozturk M, Aksoy HM, Potrykus M, Lojkowska E, 2018. Genotypic and phenotypic variability of Pectobacterium strains causing blackleg and soft rot on potato in Turkey. European Journal of Plant Pathology 152,143-155. http://dx.doi.org/10.1007/s10658-018-1459-y

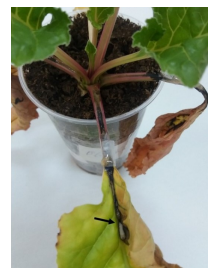

Figure 2

To cite this report: Ozturk M, Eroglu Z, Soylu S, 2019. First report of Pectobacterium betavasculorum associated with bacterial vascular necrosis and root rot disease of sugar beet in Turkey. New Disease Reports 39, 20. http://dx.doi.org/10.5197/j.2044-0588.2019.039.020 (c) 2019 The Authors This report was published on-line at www.ndrs.org. uk where high quality versions of the figures can be found. 